\title{
MANAJEMEN STRATEGI PEMERINTAH DAERAH DALAM MENINGKATKAN INVESTASI PADA CENTRAL BUSINESS DISTRICT DI KABUPATEN KEDIRI
}

\author{
Local Government Strategy Management In Increasing Investment \\ In Central Business District In Kediri Regency
}

\author{
Wahyu Setyaningrum ${ }^{1}$ \\ 1FISIP Universitas Kadiri \\ e-mail :1Wahyusetyan@yahoo.co.id
}

\begin{abstract}
Abstrak
Pemerintah daerah kabupaten/kota perlu mengupayakan pemerataan investasi dan pendapatan dengan daerah Kabupaten/Kota lainnya untuk menghindari disparitas/ketimpangan. Penelitian ini menggunakan teori manajemen strategis dan good governance. Metode penelitian pada naskah ini menggunakan metode kualitatif. Pemerintah Kabupaten Kediri mengembangkan wilayahnya untuk dijadikan tempat berinvestasi dengan membangun Simpang Lima Gumul Kabupaten Kediri. Upaya tersebut dilakukan dengan program kerja KPM (Kantor Penanaman Modal) tahun 2012. Dalam program kerja tersebut terdapat manajemen pada KPM berupa planning, organizing, actuating dan controlling. KPM melaksanakan manajemen strategi, salah satu alat manajemen strategi melalui analisa SWOT (Strenghts, Weakness, Opportunity, dan Threats). Selama ini investor pada SLG masih satu investor, yaitu PT. Gumul Paradise Island. Hal ini dikarenakan sulitnya untuk mendapatkan investor karena bersaing dengan Kota Kediri yang lebih strategis lokasinya. KPM dalam melaksanakan manajemen strategi menggunakan analisa SWOT. Analisa yang dilakukan dengan mengetahui keberhasilan, kegagalan, faktor penghambat, dan faktor pendukung organisasi dalam melaksanakan tugasnya. Setelah itu, KPM mendapatkan solusi dari masalah yang dihadapi serta dapat melaksanakan perencanaan dan pengembangan program kerja untuk menghadapi tantangan ke depan. Pembentukan suasana yang kondusif untuk berinvestasi, nvestor memerlukan pelayanan yang baik dan mudah dalam penanaman modal. Penelitian ini dilaksanakan tahun 2012, merupakan tema yang menarik untuk penelitian selanjutnya pada pengembangan investasi Kabupaten Kediri.
\end{abstract}

Kata Kunci: Manajemen Strategi; Pemerintah Daerah; Investasi Daerah; Central Business District

\begin{abstract}
District/city regional governments need to seek equal investment and income with other District/City regions to avoid disparity/ inequality. This study uses strategic management theory and good governance. The research method in this text uses qualitative methods. The Government of Kediri Regency develops its territory to be used as a place of investment by building Gumul Lima Junction Kediri Regency. This effort was carried out with the 2012 KPM (Investment Office) work program. In the work program there was management at KPM in the form of planning, organizing, actuating and controlling. KPM implements strategy management, one of the strategy management tools through SWOT analysis (Strengths, Weakness, Opportunity, and Threats). So far, investors in SLG are still one investor, namely PT. Gumul Paradise Island. This is because it is difficult to get investors because it competes with Kediri City which is more strategically located. KPM in implementing strategic management uses SWOT analysis. Analysis is done by knowing the successes, failures, inhibiting factors, and supporting factors of the organization in carrying out its duties. After that, KPM gets a solution to the problems faced and can carry out the planning and development of work programs to face the challenges ahead. Establishing an atmosphere that is conducive to investing, investors need good and easy services in investing. This research was carried out in 2012, an interesting theme for further research on the development of investment in Kediri Regency.
\end{abstract}

Keywords: Strategy Management; Local Government; Regional Investment; Central Business District 


\section{A.}

\section{PENDAHULUAN}

Di negara-negara berkembang terjadi dilema antara pertumbuhan lawan distribusi (pemerataan) pendapatan. Pembangunan menuntut GNP lebih tinggi, dan tingkat pertumbuhan yang lebih tinggi jelas perlu lebih dipacu. Pertumbuhan muncul hanya pada beberapa sektor, hal ini mengakibatkan pertumbuhan ekonomi yang tidak merata. Aspek distribusi atau pemerataan pendapatan ternyata makin timpang dalam tahun-tahun belakangan ini. Banyak orang merasa pertumbuhan ekonomi yang telah gagal memberantas, atau mengurangi kemiskinan absolut yang begitu meluas (Mynt, Hla, 1965) dalam (Sumitro, 1994:107-111).

Indonesia merupakan negara berkembang yang terus memacu pertumbuhan ekonominya. Berbagai upaya peningkatan modal, tenaga kerja dan teknologi telah dilakukan. Upaya tersebut menghasilkan pertumbuhan ekonomi dari tahun ke tahun. Pendapatan per kapita Indonesia pada 2008 mengalami peningkatan 23,6\% dibanding 2007 lalu. Pertumbuhan Produk Domestik Bruto (PDB) tahun 2009 meningkat sebesar 4,5\% terhadap tahun 2008. Pertumbuhan PDB tanpa migas pada tahun 2009 mencapai 4,9\%. Pendapatan per kapita Indonesia atas dasar harga berlaku pada 2010 tercatat mencapai $\mathrm{Rp} 27$ juta atau setara dengan 3.004,9 dollar AS. Angka ini naik sekitar $13 \%$ bila dibandingkan pada 2009 lalu. Bank Dunia memprediksikan pertumbuhan ekonomi Indonesia pada 2011 ditargetkan bisa melampaui $6,4 \%$ bahkan bisa mencapai angka $7 \%$ apabila pemerintah Indonesia melakukan reformasi secara menyeluruh pada berbagai bidang termasuk pembenahan infrastruktur. (http://www.bps.go.id).

Kenaikan GNP tersebut juga diikuti dengan kenaikan jumlah disparitas (ketidakmerataan) pertumbuhan. Seringkali pertumbuhan ekonomi hanya terjadi pada kotakota besar. Arus perekonomian di kota besar lebih tinggi dan daya beli masyarakatnya tinggi. Selama ini, kota besar mempunyai daya tarik yang tinggi. Penduduk dari desa lebih memilih bekerja di kota karena faktor ekonomi dan fasilitas di kota yang lebih memadai. Selain itu, tingkat penghasilan di kota lebih besar daripada di desa. Kebanyakan penduduk lebih mempunyai kesempatan kerja di sektor informal di kota.

Kabupaten Kediri mengalami disparitas yang cukup tinggi. Adanya disparitas dapat dilihat dari PDRB ADH. PDRB ADH adalah daya beli masyarakat berdasarkan penghasilan. Pada tahun 2006, PDRB ADH Kabupaten Kediri sebesar 6.22, sedangkan PDRB ADH kota besar jauh lebih tinggi seperti Surabaya sebesar 44.04, Sidoarjo sebesar 14.07, dan Malang sebesar 25.84. (http://mkp.fisip.unair.ac.id). Selain itu, pendapatan per kapita masyarakat Kabupaten Kediri juga masih jauh jika dibandingkan dengan kota di daerah Jawa Timur, seperti Kota Kediri, Kota Blitar dan Kota Madiun. Dapat dilihat pada tabel sebagi berikut:

\section{Tabel 1}

Pendapatan Per Kapita Jawa Timur Tahun 2006

\begin{tabular}{|c|c|c|c|}
\hline No & Kabupaten/Kota & $\begin{array}{l}\text { Jumlah } \\
\text { Penduduk } \\
\text { (Jiwa) }\end{array}$ & $\begin{array}{c}\text { PDRB } \\
\text { Perkapita } \\
\text { (ribu rp) }\end{array}$ \\
\hline 1 & Kabupaten Kediri & 1.478 .381 & $4.371,24$ \\
\hline 2 & Kota Kediri & 253.260 & $87.183,03$ \\
\hline 3 & $\begin{array}{l}\text { Kabupaten } \\
\text { Tulungagung }\end{array}$ & 966.984 & $5.782,93$ \\
\hline 4 & Kota Blitar & 124.213 & $8.748,30$ \\
\hline 5 & Kabupaten Blitar & 1.119 .386 & $3.305,78$ \\
\hline 6 & $\begin{array}{l}\text { Kabupaten } \\
\text { Trenggalek }\end{array}$ & 674.748 & $2.674,37$ \\
\hline 7 & KabupatenNganjuk & 1.033 .409 & $3.297,18$ \\
\hline 8 & Kabupaten Jombang & 1.179 .371 & $3.827,58$ \\
\hline 9 & Kabupaten Madiun & 658.278 & $3.550,06$ \\
\hline 10 & Kota Madiun & 170.335 & $10.558,97$ \\
\hline 11 & $\begin{array}{l}\text { Kabupaten } \\
\text { Ponorogo }\end{array}$ & 878.389 & $3.409,59$ \\
\hline 12 & Kabupaten Pacitan & 545.316 & $3.139,73$ \\
\hline 13 & Kabupaten Magetan & 625.976 & $4.500,86$ \\
\hline 14 & Kabupaten Ngawi & 850.972 & $3.497,62$ \\
\hline & Jumlah & 10.558 .468 & \\
\hline
\end{tabular}

Sumber: Kantor Penanaman Modal Kabupaten Kediri

Manajemen strategi adalah perencanaan yang berorientasi pada visi, dan ditetapkan sebagai keputusan manajemen dalam rangka pencapaian tujuan organisasi tersebut. Dalam perkembangannya sektor publik telah mengalami perubahan sejalan dengan perubahan paradigma administrasi publik. Administrasi publik konvensional dianggap gagal mencapai tujuan organisasi secara efektif dan efisien, lebih mementingkan proses daripada hasil sehingga munculnya paradigma new public management.

Manajemen strategi pada sektor publik perlu adanya rencana strategi dan manajemen kinerja agar mempermudah pencapaian tujuan, juga pada kinerja yang mudah diukur sehingga menciptakan akuntabilitas kinerja pada suatu organisasi. Pada sistem akuntabilitas kinerja harus ada suatu proses perencanaan, pengukuran, pelaporan dan pemanfaatan informasi kinerja dalam manajemen strategi. Perlunya suatu organisasi dalam manajemen strategi adalah dapat mengurangi ketidakpastian dalam suatu perencanaan, sebagai pengendali sehingga visi dan misi dapat terkontrol yang mendorong perilaku proaktif untuk ikut serta dalam mewujudkan keunggulan organisasi.

Manajemen strategi dapat diukur dengan meangevaluasi atau meninjau kembali 
permasalahan apakah terjadi perubahan pada saat pengukuran kemampuan organisasi dengan memastikan kembali apakah sudah sesuai dengan standar yang telah ditetapkan, juga dapat mengetahui perkembangan perbaikan dalam pengembangan model dimasa mendatang.

Pemerintah daerah menggunakan manajemen strategi sebagai sarana untuk menentukan arah kebijakan organisasi Pemerintah Daerah. Di dalam pengelolaan pendapatan daerah juga diperlukan manajemen strategi. Pengelolaan pendapatan daerah dapat diberdayagunakan dan daya hasil yang untuk memenuhi belanja daerah. Di dalam melakukan kegiatan operasionalnya dalam kegiatan pelayanan maupun dalam kegiatan peningkatan perekonomian, pemerintah daerah memerlukan angaran dana yang cukup. Dengan demikian diperlukan adanya sumber-sumber pendapatan daerah. Pemerintah daerah dapat menggali sumber-sumber daya yang berpotensi untuk menghasilkan dan menambah Pendapatan Asli Daerah.

Pendapatan Pemerintah Daerah dari pajak dapat berupa pajak dari Penanaman Modal Asing dan Penanaman Modal Dalam Negeri (PMA dan PMDN). Dalam melaksanakan tugasnya untuk menggali potensi daerah yang ada, pemerintah daerah memerlukan bantuan perusahaan swasta untuk dipungut pajaknya dan menambah PAD. Selain itu, dengan adanya PMA dan PMDN yang menanamkan modalnya pada daerah juga dapat membuka lapangan pekerjaan untuk masyarakat, memenuhi kebutuhan pelayanan dan kebutuhan barang publik dan memberikan kemajuan bagi daerah tersebut terkait dengan modernisasi sehingga mengurangi disparitas kemajuan wilayah satu dengan wilayah lainnya.

Seiring dengan perkembangan kegiatan perekonomian yang sangat pesat dan terjadinya disparitas kemajuan wilayah, maka diperlukan cara untuk segera mengantisipasi kondisi tersebut dan menarik arus pergerakan ekonomi ke wilayah. Oleh karena itu pengembangan wilayah pada masa sekarang lebih diarahkan ke arah pembangunan ekonomi. Situasi problematis inilah yang mendorong Pemerintah Kabupaten Kediri melaksanakan pembangunan Central Business District (CBD). Dengan adanya pembangunan CBD, pemerintah Kabupaten Kediri mempunyai tujuan untuk investor tertarik berinvestasi pada Kabupaten

Kediri (http:/ / creativity4live.blogspot.com).

Penanaman Modal Kabupaten Kediri, untuk merealisasikan mega proyek seluas 37 hektar tersebut dibutuhkan investasi sebesar Rp 1 triliun lebih. Untuk itu, Pemerintah Kabupaten
Kediri mengundang investor dalam negeri khususnya yang ada di Surabaya untuk berinvestasi. Sejauh ini, fasilitas yang sudah terbangun di sana adalah monumen SLG, infrastruktur dasar seperti akses jalan, pasar dan perbankan. Pemerintah Kabupaten Kediri juga segera mendirikan tempat hiburan air atau water park dan pusat perbelanjaan di kawasan monumen Simpang Lima Gumul (SLG). Pembangunan water park dan pusat perbelanjaan ini merupakan salah satu upaya untuk mempercepat pertumbuhan kawasan SLG. (http:/ / creativity4live.blogspot.com).

Sumber pembiayaan pembangunan tersebut tidak akan menggunakan dana Anggaran Pendapatan Belanja Daerah Kabupaten Kediri. Hal ini dikarenakan telah adanya tawaran kerjasama dari konsorsium pengusaha yang bersedia mengucurkan dana Rp 100 miliar dari PT. Panorama Wisata Sejahtera. Sementara untuk pembangunan fasilitas lainnya seperti trade center atau mall dan hotel masih diusahakan.

Dalam keefektifan pencapaian suatu tujuan, yaitu tujuan peningkatan investasi pada area CBD, dibutuhkan manajemen strategi dari Pemerintah Daerah untuk menarik investor. Dibutuhkan arah kebijakan pembangunan yang jelas. Tujuan utama pembangunan CBD Simpang Lima Gumul Kabupaten Kediri dapat terwujud dengan adanya pertumbuhan ekonomi dan pengembangan wilayah yang memerlukan investasi dari pihak swasta, maka Pemerintah Daerah Kabupaten Kediri pada tahun 2009 membentuk lembaga Kantor Penanaman Modal. Kantor Penanaman Modal perlu membuat rencana strategis berkaitan dengan tujuan jangka panjang Pemerintah Kabupaten Kediri untuk membangun CBD dan penarikan investor untuk menanamkan modalnya.

Berdasarkan pada latar belakang di atas, maka penelitian ini mengambil judul "Manajemen Strategi Pemerintah Daerah Dalam Meningkatkan Investasi Pada Central Business District Di Kabupaten Kediri". Rumusan masalah penelitian ini, yaitu:

1. Bagaimana manajemen Kantor Penanaman Modal dalam Central Business District?

2. Bagaimana manajemen strategi Kantor Penanaman Modal dalam Central Business District?

\section{B. LANDASAN TEORITIS}

\section{1) 1) Manajemen Strategi}


Manajemen strategi terdiri atas dua suku kata yang dapat dipilah menjadi kata manajemen dan strategi. Manajemen merupakan serangkaian proses yang terdiri atas perencanaan (planning), pengorganisasian (organizing), pelaksanaan (actuating), pengawasan (controlling) dan penganggaran (budgeting) (Nawawi, 2003:52) dalam (Bawono, 2009:5)

Unsur - unsur yang ada dalam manajemen tersebut apabila dijabarkan dalam penjelasan adalah sebagai berikut :

1) Perencanaan (Planning)

2)Pengorganisasian (Organizing)

3) Pelaksanaan (Actuating)

4)Penganggaran (Budgeting)

5)Pengawasan (Control)

Sedangkan kata yang kedua adalah strategi yang berasal dari bahasa Yunani strategos atau strategeus dengan kata jamak strategi. Strategos berarti jenderal, namun dalam Yunani kuno sering berarti perwira negara (state officer) dengan fungsi yang luas (Salusu, 2003 :85 ) dalam (Bawono, 2009:6) Pendapat yang lain mendefinisikan strategi sebagai kerangka kerja (frame work), teknik dan rencana yang bersifat spesifik atau khusus (Rabin et.al, 2000:15) dalam (Bawono, 2009:6). Hamel dan Prahalad dalam Umar (2002) dalam (Bawono, 2009:6) menyebutkan kompetensi inti sebagai suatu hal yang penting. Mereka mendefinisikan strategi menjadi :

Strategi merupakan tindakan yang bersifat incremental ( senantiasa meningkat) dan terus menerus, serta dilakukan berdasarkan sudut pandang tentang apa yang diharapkan oleh para pelanggan di masa depan. Dengan demikian, strategi hampir selalu dimulai dari apa yang dapat terjadi dan bukan dimulai dengan apa yang terjadi. Terjadinya kecepatan inovasi pasar yang baru dan perubahan pola konsumen memerlukan kompetensi inti (core competencies). Perusahaan perlu mencari kompetensi inti di dalam bisnis yang dilakukan.

Manajemen strategi merujuk pada proses manajerial untuk membentuk visi strategi, penyusunan obyektif, penciptaan strategi mewujudkan dan melaksanakan strategi dan kemudian sepanjang waktu melakukan penyesuaian dan koreksi terhadap visi, obyektif strategi dan pelaksanaan tersebut. Sedangkan Siagian (2004) dalam (Bawono, 2009:8) mendefinisikan manajemen stratejik sebagai berikut : "Serangkaian keputusan dan tindakan mendasar yang dibuat oleh manajemen puncak dan diimplementasikan oleh seluruh jajaran suatu organisasi dalam rangka pencapaian tujuan organisasi tersebut. "

\section{2) Good Governance}

Secara umum, good governance atau kepemerintahan yang baik, dapat diartikan, yaitu: dijalankannya dengan baik (good) ketiga domain yang ada dalam governance atau kepemerintahan. Ketiga domain governance itu adalah: (1) negara atau pemerintah (state); (2) sektor swasta atau dunia usaha (private sector): dan (3) masyarakat (society). Secara konseptual pengertian kata baik (good) dalam istilah kepemerintahan yang baik (good governance) mengandung dua pemahaman, yaitu: pertama, nilai-nilai yang menjunjung tinggi keinginan/kehendak rakyat, dan nilai-nilai yang dapat meningkatkan kemampuan rakyat dalam pencapaian tujuan (nasional) kemandirian, pembangunan berkelanjutan, dan keadilan sosial. Kedua, aspek-aspek fungsional dari pemerintahan yang efektif dan efisien dalam pelaksanaan tugasnya untuk mencapai tujuantujuan tersebut. (Indardi, 2005:10)

Oleh karena itu, berdasarkan pengertian ini, kepemerintahan yang baik berorientasi pada dua hal, yaitu: pertama, orientasi ideal negara, yang diarahkan pada pencapaian tujuan nasional. Hal ini memacu pada demokratisasi dalam kehidupan bernegara dengan elemen-elemen konstituen atau pemilihnya, seperti: legitimasi, akuntabilitas, adanya otonomi dan devolusi kekuasaan pada daerah, serta adanya jaminan berjalannya mekanisme kontrol oleh masyarakat. Kedua, pemerintahan yang berfungsi secara ideal, yaitu secara efektif dan efisien melakukan upaya pencapaian tujuan nasional. Hal ini sangat tergantung pada sejauh mana pemerintah pempunyai kompetisi, dan sejauh mana struktur serta mekanisme politik dan administrasi berfungsi secara efektif dan efisien. (Indardi, 2005:10)

OECD dan World Bank, mensinonimkan good governance dengan penyelenggaraan manajemen pembangunan yang solid dan bertanggungjawab. Sejalan dengan demokrasi dan pasar yang efisien, penghindaran salah alokasi dan investasi yang langka, dan pencegahan korupsi, baik secara politik maupun administratif, menjalankan disiplin anggaran serta penciptaan legal and political framework bagi tumbuhnya aktivitas kewiraswastaan. Dokumen yang diterbitkan oleh UNDP dan pemerintah Vietnam mendefinisikan good governance sebagai proses yang meningkatkan interaksi konstruktif diantara omain-domainnya dengan tujuan untuk menciptakan dan memelihara kebebasan, keamanan dan kesempatan bagi adanya aktivitas swasta yang produktif. Oleh karena itu, good governance juga adalah mengutamakan partisipasi, transparansi, akuntabilitas dan efektivitas serta 
memperlakukan semua sama. Sementara UNDP sendiri memberikan definisi good governance sebagai "hubungan sinergis dan konstruktif diantara negara (state), sektor swasta (private sector) dan masyarakat (society)". Dengan kata lain, hubungan sinergis dan konstruktif diantara ketiga domain yang terdapat dalam governance atau kepemerintahan. (Indardi, 2005:11)

\section{METODE PENELITIAN}

Dengan berpijak dari permasalahan yang diteliti, peneliti memilih bentuk penelitian kualitatif. Bogdan dan Taylor dalam (Moleong, 2008:4) mengemukakan bahwa "metodologi kualitatif sebagai prosedur penelitian yang menghasilkan data deskriptif berupa kata-kata tertulis atau lisan dari orang-orang dan perilaku yang dapat diamati".

Menurut Lofland dan Lofland dalam Lexy J. Moleong (2008:157) "sumber data utama dalam penelitian kualitatif ialah kata-kata dan tindakan, selebihnya adalah data tambahan seperti dokumen dan lain-lain".

Teknik pengumpulan data merupakan cara atau teknik yang digunakan untuk mendapatkan data yang diperlukan untuk menjawab permasalahan dalam penelitian. Teknik pengumpulan data yang digunakan dalam penelitian ini adalah:
1. Wawancara
2. Observasi
3. Dokumentasi

\section{PEMBAHASAN}

\section{1) Manajemen Kantor Peanaman Modal Kabupaten Kediri dalam Central Business District.}

Pemerintah Kabupaten Kediri berinisiatif untuk memanfaatkan segala potensi daerah yang ada. Hal tersebut dilakukan untuk meningkakan perekonomian masyarakat maupun untuk peningkatan PAD. Salah satu upaya Pemkab Kediri dalam memanfaatkan potensi yang ada dengan membentuk ikon Kabupaten Kediri. Ikon tersebut berupa SLG Kabupaten Kediri. SLG tersebut direncanakan akan menjadi CBD (Central Business District).

Pemerintah Kabupaten Kediri membutuhkan investor baik dari lokal, PMDN (Penanaman Modal Dalam Negeri) maupun PMA (Penanaman Modal Asing). Investor tersebut dapat berinvestasi pada area SLG. Pemerintah Kabupaten Kediri membangun fasilitas awal berupa jalan raya, monumen, listrik dan penjagaan keamanan. Hal ini digunakan sebagi langkah awal untuk menarik investor. Selama ini investor lebih tertarik berinvestasi pada kota besar seperti Surabaya dan Kota Kediri. Dengan adanya SLG, akan menjadi daya tarik bagi investor.

Pemerintah Kabupaten Kediri membentuk KPM untuk menunjang dan memfasilitasi dalam penarikan investor pada Kabupaten Kediri dengan selesainya pembangunan SLG dari tahun 2002-2008. Pada tahun 2008 dilakukan proses pembentukan KPM. KPM dibentuk berdasarkan SK Bupati dan SK tupoksi KPM. KPM melaksanakan tugasnya berdasarkan program, kegiatan dan sasaran yang telah direncanakan dalam RKPD KPM (Rencana Kerja Pemerintah daerah Kantor Penanaman Modal). RKPD tersebut disusun berdasarkan Visi dan Misi KPM. Sedangkan Visi dan Misi KPM direncanakan dari rapat awal tahun pembentukan organisasi dan kepengurusan. Selama tahun 20092015 Visi dan Misi KPM belum berubah. Tujuan,visi dan misi KPM berdasarkan Kebijakan RPJP dan RPJM Pemerintah daerah.

Keberadaan Kantor Penanaman Modal Kabupaten Kediri adalah kantor baru di lingkup Pemerintahan Kabupaten Kediri, kantor investasi tersebut mempunyai tugas yang cukup berat terutama di Kabupaten Kediri yang menurut beberapa pihak minim akan investasi dari investor lokal atau investor dari luar Kediri. Minimnya investasi di Kabupaten Kediri seperti beberapa di beritakan yang lalu salah satunya para pengusaha yang mengeluhkan karena banyaknya "pungutan" bagi para investor yang akan menanamkan usaha di Kabupaten Kediri. (www.suaramedia.com)

Para pengusaha baik lokal Kediri maupun dari luar Kediri tersebut lebih suka menanamkan modal usahanya di kota Kediri daripada di Kabupaten Kediri. Sehingga beberapa bulan yang lalu kota Kediri tercatat menjadi kota Kediri masuk dalam rangking salah satu kota yang banyak mendatangkan investor. Memang menurut beberapa kalangan keberadaan kantor investasi tersebut di nilai belum memberi peningkatan yang signifikan akan masuknya para investor baik itu dari lokal Kediri terlebih penanam modal dari luar Kediri apalagi investor dari luar negeri. Hal itu terlihat dari minimnya investor masuk ke Kabupaten Kediri padahal potensi yang di miliki oleh Kabupaten Kediri sangat potensial untuk daerah wisata maupun untuk usaha.(www.suaramedia.com)

Anggapan tersebut teridentifikasi sebagai tantangan yang dihadapi dalam memberdayakan penanaman modal, dan telah juga diakui oleh Pemerintah Kabupaten Kediri dalam Rencana Strategis KPM Tahun 2012 Kendala dan tantangan tersebut antara lain (Chandra, 2007:1): 
1. Masih rendahnya kepastian hukum.

2. Lemahnya insentif investasi.

3. Masih tingginya biaya ekonomi, karena tingginya kasus korupsi, keamanan dan penyalah gunaan wewenang.

4. Meningkatnya nilai tukar riil efektif rupiah. Sebagai bagian strategi pengelolaan penanaman modal, pemberian kesempatan pengusaha untuk melakukan kegiatan pembangunan prasarana infrastruktur, prosedur pengurusan perijinan yang mudah, cepat dan murah, serta penegakan hukum dalam pemberantasan korupsi. Terpenting yang lainnya adalah, undang-undang penanaman modal asing yang memberikan kelonggaran repatriasi modal maupun laba perusahaan, dan jangka waktu perijinan investasi serta hak pengelolaan yang semakin diperpanjang.

Terbitnya Undang-undang Nomor 25 tahun 2007 tentang Penanaman Modal, perlu dibangun konsep yang integral untuk menghadapi berbagai implikasi negatif dari penanaman modal asing dan pasar bebas. Strategi peningkatan investasi melalui program aksi bidang iklim investasi dan iklim usaha sebagaimana menjadi prioritas rencana strategis KPM tahun 2012 berikut perlu dikawal perwujudannya, yaitu :

1. Kepastian hukum: Reformasi regulasi secara bertahap di tingkat daerah dan daerah sehingga terjadi harmonisasi peraturan perundangundangan yang tidak menimbulkan ketidakjelasan dan inkonsistensi dalam implementasinya.

2. Penyederhanaan prosedur: Penerapan sistem pelayanan perizinan secara elektronik (SPPSE) pada Pelayanan Terpadu Satu Pintu (PTSP), pembatalan perda bermasalah dan pengurangan biaya untuk memulai usaha seperti Tanda Daftar Perusahaan (TDP) dan Surat Ijin Usaha Perdagangan (SIUP).

3. Logistik nasional: Pengembangan dan penetapan Sistem Logistik Nasional yang menjamin kelancaran arus barang dan mengurangi biaya transaksi/ekonomi biaya tinggi melalui BPM dan BKPM.

4. Sistem informasi: Beroperasinya secara penuh National Single Window (NSW) untuk impor (sebelum Januari 2010) dan ekspor.

6. Kebijakan ketenagakerjaan: Sinkronisasi kebijakan ketenagakerjaan dan iklim usaha dalam rangka penciptaan lapangan kerja.

Dalam penelitian ini, akan mendekripsikan tugas yang berkaitan dengan Pembangunan Investasi pada Simpang Lima Gumul. Tugas ini direncanakan dalam RKPD KPM 2012.. Pelaksanaan program sampai saat ini sedang berlangsung pada tahun 2012. Terdapat program dan kegiatan yang dikerjakan pada tahun 2012 dan baru selesai pada tahun 2013, seperti pmbentukan PTSP (Pelayanan Terpadu Satu Pintu). Manajemen strategi tahun 2012 ini dilaksanakan melalui proses manajemen. Manajemen strategi KPM terdiri dari perencanaan (planning), pengorganisasian (organizing), pelaksanaan (actuating), pengawasan (controlling) dan penganggaran (budgeting).

\section{a) Planning (Perencanaan)}

Tugas intern pada Kantor Penanaman modal direncanakan melalui lima Program, yaitu Program Pelayanan Administrasi Perkantoran, Program Peningkatan Sarana dan Prasarana Aparatur, Program Peningkatan Pengembangan Sistem Pelaporan Capaian Kinerja dan Keuangan, Serta Program Peningkatan Promosi dan Kerja Sama Investasi.

\section{b) Organizing (Pengorganisasian)}

Dalam melaksanakan tugasnya sesuai dengan perencanaan strategi yang dilakukan, pengorganisasian pada KPM sesuai dengan program kerjanya. KPM dalam melakukan pengorganisasian tidak ada perubahan dari tahun 2009, 2010. Sedangkan pada tahun 2011-2015 terdapat perubahan pada kegiatan kerja. Namun tidak mempengaruhi struktur organisasi KPM. Terdapat penambahan kegiatan Kerja yaitu, pembentukan SPSE (Sistem Pelayanan Perijinan Secara Elektronik), Dewan Pengembangan Investasi dan PTSP (Pelayanan Terpadu Satu Pintu).

\section{c) Actuating (Pelaksanaan)}

Pelaksanaan atau penggerakan dilakukan organisasi setelah sebuah organisasi memiliki perencanaan dan melakukan pengorganisasian dengan memiliki struktur organisasi termasuk tersedianya personil sebagai pelaksana sesuai dengan kebutuhan unit atau satuan kerja yang dibentuk. Tugas intern pada Kantor Penanaman modal direncanakan melalui program, kegiatan dan sasaran, yaitu:

$>$ Program Pelayanan Administrasi Perkantoran dan Program Peningkatan Sarana dan Prasarana Aparatur

$>$ Program Peningkatan Pengembangan Sistem Pelaporan Capaian Kinerja dan Keuangan.

$>$ Program Peningkatan Promosi dan Kerja Sama Investasi

$>$ Program Peningkatan Iklim Investasi dan Realisasi Investasi 


\section{d) Controlling}

Pada manajemen strategi KPM, terdapat pealaksanaan controlling dalm implementasi KPM menjalankan tuasnya. Pengawasan kinerja berada pada Kepala KPM (Bapak Ir. Andes Erwanto, MM) langsung terhadap bidang promosi dan kerja sama, bidang operasional, bidang perencanaan dan pengembangan serta bidang pelayanan dan pembinaan. Pengawasan berlangsung setiap hari. Pegawai harus menjalankan tugasnya sesuai dengan Tupoksi dari masing-masing bidang. Pengawasan juga berdasarkan capaian kerja yang tertulis pada program kerja. Jika terjadi ketidak disiplinan, maka akan diperingatkan. Dalam hal ini, pengawasan kinerja juga berkaitan dengan LAKIP pada akhir tahun. Selanjutnya LAKIP tersebut diserahkan pada Bupati dan Pemprov.

Selain pengawasan dari Kepala Kantor, Kepala Kabupaten dan pemerintah provinsi, juga tedapat pengawasan dan pembinaan pada KPM. KPM dibina dan diawasi oleh BPM (Badan Penanaman Modal). BPM mengatur penanaman modal pada tingkat provinsi, sedangkan BKPM (Badan Kinerja Penanaman Modal) berada pada tingkat nasional. Badan ini memberikan informasi terbaru mengenai penanaman modal dan dapat melakukan pendampingan pada Badan Penanaman modal di daerah.

\section{5) Budgeting}

KPM melaksanakan tupoksinya dalam Penanaman modal memerlukan dana. Kediatan KPM didanai dari APBD. Dana tersebut digunakan untuk pembiayaan program dan kegiatan KPM. Dalam penganggaran tahun 2012, KPM melaksaksanakan berdasarkan rencana kerja besar anggaran sesuai dengan rencana kerja. Penggunaan dana KPM sudah tepat sasaran dan sesuai dengan perencanan.

\section{2) Manajemen Kantor Penanaman Modal Kabupaten Kediri dalam Central Business District.}

Analisa SWOT merupakan salah satu alat dalam manajemen stratejik untuk menentukan kekuatan (strength), kelemahan (weakness), kesempatan (opportunity) dan ancaman (threat) dalam organisasi seperti pada tabel 1. berikut ini.

Tabel 1. Analisa SWOT Pada KPM Kabupaten Kediri

\begin{tabular}{|c|c|}
\hline Strengths & Weakness \\
\hline $\begin{array}{l}\text { 1) Adanya mandat } \\
\text { yang diberikan oleh } \\
\text { pemerintah kepada } \\
\text { Kantor Penanaman } \\
\text { Modal untuk } \\
\text { melaksanakan tugas } \\
\text { pokok dan fungsi, yaitu } \\
\text { berdasarkan Peraturan } \\
\text { Daerah Kabupaten } \\
\text { Kediri Nomor 36 Tahun } \\
\text { 2008 tentang Organisasi } \\
\text { dan tata kerja Kantor } \\
\text { Penanaman Modal } \\
\text { 2) Adanya } \\
\text { komitmen yang tinggi } \\
\text { anggota organisasi } \\
\text { terhadap organisasinya } \\
\text { 3) Adanya jejaring yang } \\
\text { telah terbangun dengan } \\
\text { baik dengan instansi } \\
\text { pemerintah lain. Dalam } \\
\text { hal ini, KPM melakukan } \\
\text { kerjasama dengan } \\
\text { Kantor dagang Jerman } \\
\text { dan Perancis, KPM } \\
\text { pusat dan provinsi, dan } \\
\text { pengusaha di daerah } \\
\text { Jawa Timur }\end{array}$ & 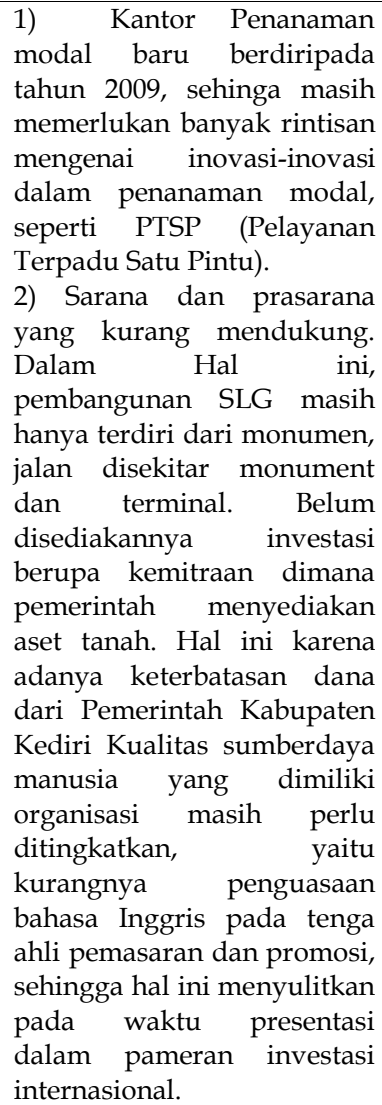 \\
\hline Oportunities & Threats \\
\hline 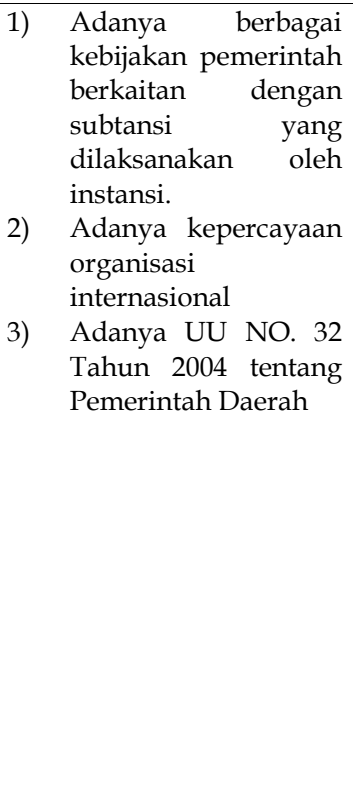 & 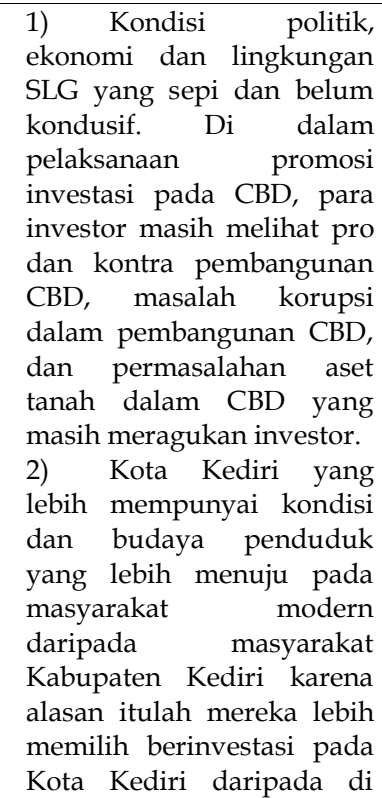 \\
\hline
\end{tabular}


pelayanan yang baik dan mudah dalam penanaman modal. Dengan adanya fasilitas tersebut diharapkan akan cepat menarik investor karena kemudahan berinvestasi yang dijanjikan.

\section{F. REFERENSI}

Bawono, Icuk Rangga. 2010. Manajemen Strategik Sektor Publik: Langkah Tepat Menuju Good Governance. www.pdf/manajemen-strategipublik.html.

BPS. 2011. Pertumbuhan Ekonomi Indonesia. Online, http://www.bps.go.id.

Chandra, Adityawa. 2003. Strategi Menarik Penanaman Modal Asing dalam Pembangunan Ekonomi. http://businessenvironment.word press.com.

Indardi, Sjamsiar Sjamsuddin. 2008. Administrasi Pemerintahan Lokal. Malang: Agritek YPN

Karnaji. 2010. Disparitas Antar Wilayah Jawa Timur. http:/ / mkp.fisip.unair.ac.id

Moleong, Lexy J. 2008. Metode Penelitian Kualitatif. Jakarta: Bumi Aksara

Sumitro, Djojohadikusumo. 1994. Perkembangan pemikiran Ekonomi. Dasar teori ekonomi pertumbuhan dan ekonomi pembangunan. Jakarta:LP3ES

Tanpa Nama. 2011. SLG (Simpang Lima Gumul), Megaproyek Kawasan CBD Baru Kabupaten Kediri. http:/ / creativity4live.blogspot.com.

Tanpa Nama. Tanpa Tahun. Central Business District. Online, www.wikipedia.com.

Tanpa Nama. 2010. Peran Kantor Penanaman Modal Kabupaten Kediri Tidak Maksimal. www.suaramedia.com.

Undang-undang Nomor 32 Tahun 2004 tentang Pemerintah Daerah

Undang-undang Nomor 25 Tahun 2007 tentang Penanaman Modal

dari masalah yang dihadapi serta dapat melaksanakan perencanaan dan pengembangan program kerja untuk menghadapi tantangan ke depan.

2) Saran

Sebaiknya, KPM segera menyelesaikan pembentukan Dewan Pengembangan Investasi, PTSP dan SPPSE. Investor memerlukan 